Article

\title{
Evaluation of Vegetation Restoration along an Expressway in a Cold, Arid, and Desertified Area of China
}

\author{
Chunfeng Jia ${ }^{1,2,3}$, Bao-ping Sun ${ }^{1, *}$, Xinxiao Yu ${ }^{1}$ and Xiaohui Yang ${ }^{4}$ \\ 1 School of Soil and Water Conservation Beijing Forestry University, Beijing 100083, China; \\ jiachunfeng@bjfu.edu.cn (C.J.); yuxinxiao111@bjfu.edu.cn (X.Y.) \\ 2 Shanxi Environmental Protection Institute of Transport (co., LTD.), Taiyuan 030006, China \\ 3 Shanxi Transportation Research Institute, Taiyuan 030006, China \\ 4 Chinese Academy of Forestry, Beijing 100091, China; xiaohuiyang@caf.ac.cn \\ * Correspondence: sunbaoping@bjfu.edu.cn; Tel.: +86-010-6233-8068
}

Received: 28 March 2019; Accepted: 13 April 2019; Published: 17 April 2019

\begin{abstract}
Vegetation restoration plays a significant role in the restoration of expressways in the arid zone of China, but we still do not know which soil and vegetation types are most effective. We investigated soil particle size (SPZ), volume weight of the soil (VWS), soil water content (SWC), total porosity of soil (TP), soil organic matter $(\mathrm{SOM})$, water erosion $\left(\mathrm{W}_{\mathrm{r}} \mathrm{E}\right)$, and wind erosion $\left(\mathrm{W}_{\mathrm{d}} \mathrm{E}\right)$ of eight sites (S1-S8) and evaluated them using the gray correlation method (GCM). Based on our results, the average SWC of the treatments ranged from $9.6 \%$ to $18.8 \%$, following the order S4 $>$ S5 > $\mathrm{S} 8>\mathrm{S} 6>\mathrm{S} 3>\mathrm{S} 7>\mathrm{S} 1>\mathrm{S} 2$. The average SPZ of soils in S1, S2, S4, S5, S6, and S8 was larger, ranging from 0.23 to $0.68 \mathrm{~mm}$, while that of soils in S3 and S7 was smaller, ranging from 0.01 to $0.09 \mathrm{~mm}$. The TP in different treatment areas ranged from $50 \%$ to $60 \%$, which is not conducive to soil and water conservation. The SOM levels varied widely among the different soils and were always below the threshold levels established by the second National Soil Census, rendering the soils not suitable for plant growth. The $W_{r} E(36-80 t / h a)$ was greater than the $W_{d} E(7-24 t / h a)$. In general, to achieve high soil and water conservation outcomes in this area, S1 and S7 offered the best protection benefits in terms of soil and water conservation.
\end{abstract}

Keywords: benefit evaluation; gray correlation method; soil erosion; soil physical properties

\section{Introduction}

The construction of expressways inevitably destroys the surface vegetation, leading to significant ecological problems such as soil erosion and landscape degradation [1-3]. In this sense, vegetation restoration along expressways is crucial to stabilize the roadbed, improve the road environment, and enhance the aesthetic properties of such areas [4-6]. During construction, the soil structure is largely destroyed; the surface soil in the cutting slope was mixed with gravel, parent material, and, in some cases, even rocks [7]. As a result, the surface temperature difference between day and night is relatively high, physical weathering is extreme, and evaporation is high; consequently, precipitation easily initiates runoffs $[8,9]$.

In this sense, vegetation restoration along expressways is challenging. Previous studies have taken a series of measures to restore expressway slopes. The traditional forms of slope vegetation protection include grass planting [10], three-dimensional vegetation networks [11], masonry stone wall establishment [12], skeleton grass planting [13], vine plant protection [14], and geogrid grass planting [15]. Slope grass planting is characterized by a low survival rate, high maintenance costs, and the frequent degradation of grass seeds, while shrub planting is restricted by the water and 
nutrient conditions of the slope [14]. Inevitably, such approaches led to a low protection effect of the slope. Some expressway greening projects were only possible with the use of engineering work [15], with large investments. Also, over time, with rock weathering, concrete aging, and steel bar erosion, the protection effects become weaker [16,17]. In the northern regions of China, cutting slopes are also highly vulnerable to wind erosion [18,19]. Especially in the greening of expressways in arid, cold, and desertified areas, this problem is more prominent and mainly manifests in the following aspects: Firstly, the project implementers emphasize short-term effects while neglecting long-term effects [20], which directly leads to the phenomenon of " 1 year green, 2 years yellow, 3 years withered, and 4 years dead". Secondly, project implementers overemphasize the quantity of greening. For example, in some arid areas, the emphasis was also on vegetation coverage, and especially in the south, evergreen trees have been planted extensively, often with unsatisfactory results. Thirdly, plant species selection and allocation were unreasonable [21], without any specific norms and standards, mainly copying the model of landscape greening and ignoring the natural laws of ecosystem and plant growth, which often resulted in unsatisfactory outcomes.

To reduce the environmental impacts of expressway construction and to improve the restoration of the damaged areas, it is crucial to employ new technologies, especially in cold, dry, and desertified areas. In this context, we included seven indices, namely volume soil weight, total porosity, soil moisture content, soil particle size, soil organic matter, water erosion, and wind erosion, from eight different treatment areas to evaluate the soil and water conservation benefits, using the gray correlation method (GCM) [22]. In this study, we summarize a set of technical methods for the ecological restoration of expressway areas in cold, dry, and desertified loess areas. The results of our study are of great significance for the restoration of vegetation along expressways, providing a reference for greening technology in other construction projects in cold, arid, and desertified areas and for technological progress of the vegetation restoration industry in general.

\section{Study Sites}

The study area is located along the Dahu Expressway $\left(113.275^{\circ} \mathrm{E}\right.$ and $\left.39.936^{\circ} \mathrm{N}\right)$ in Datong City, Shanxi Province, a typical loess plateau area in China (Figure 1), at an elevation range from 1320 to $1170 \mathrm{~m}$. The climate is north-temperate semi-arid continental monsoon climate. Due to the monsoon and high pressure on the Siberian and Mongolian plateau, there is little snow; the area experiences mild temperatures in winter, drought and windiness in spring, hot and rainy summers, and cool autumns. Average annual precipitation is $399 \mathrm{~mm}$, of which more than $60 \%$ fall from July to September. Average annual temperature is $6.1{ }^{\circ} \mathrm{C}$, with minimum and maximum temperatures of -29.5 and $34.5^{\circ} \mathrm{C}$, respectively. The daily temperature difference is $13.0^{\circ} \mathrm{C}$, with a frost-free period of 125 days. The study area can be divided into five geomorphic units, including loess hilly area, intermountain valley plain area, erosion and denudation high hilly area, valley plain area, and alluvial and flood plain area. The soil is mainly weathered rock soil, coarse silty soil, collapsible loess, and liquefaction soil of saline soil with sandy soil (Reference to China Soil Classification System). The main tree species are Pinus tabulaeformis, Larix gmelinii, and Pinus sylvestris var. mongolica. The shrub species mainly include Hippophae rhamnoides Linn. and Caragana korshinskii, while the most abundant herb genera are Carex and Artemisia. The above information was obtained by consulting local historical meteorological data and the respective yearbook. 


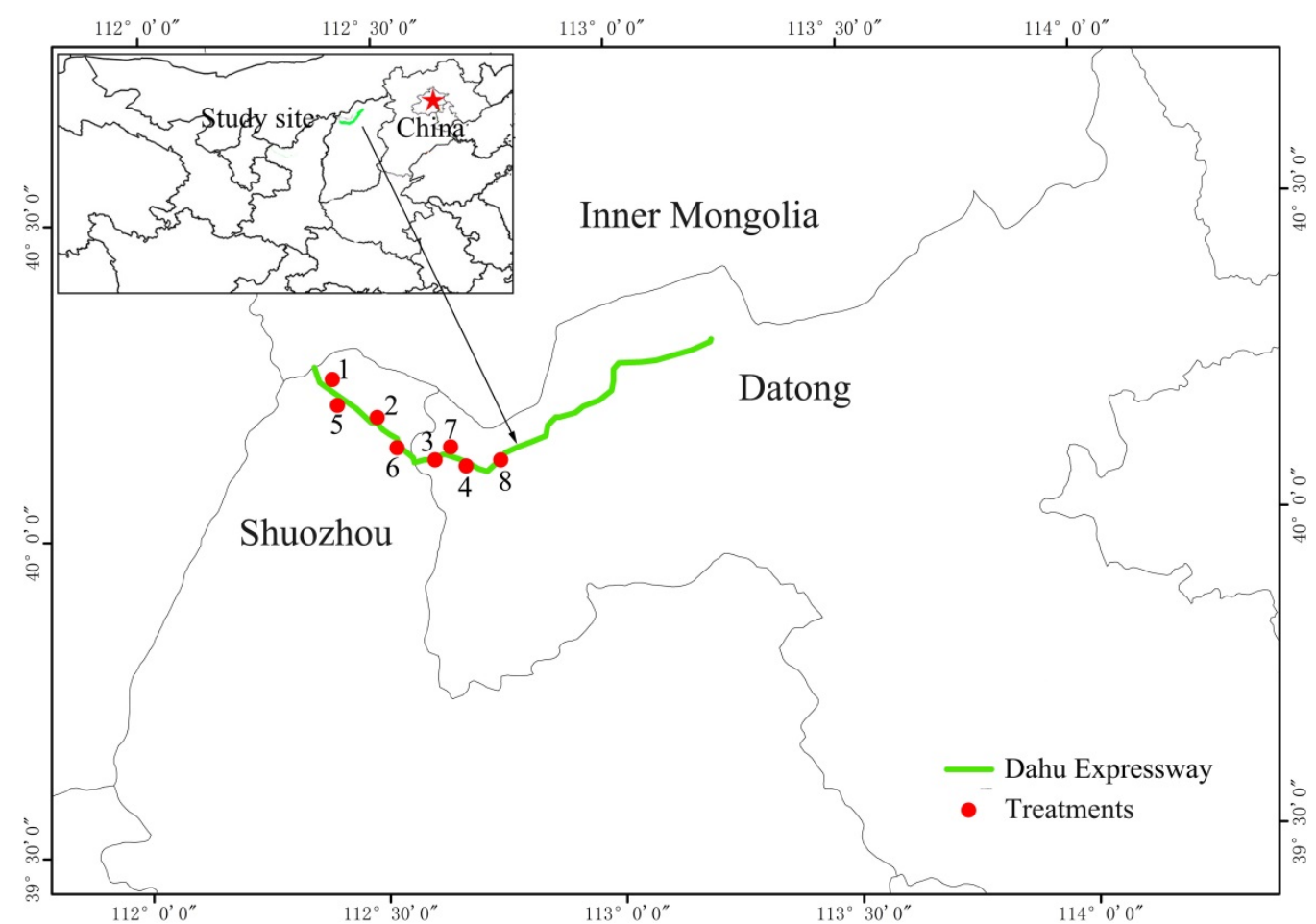

Figure 1. Geographic map of the study area. The numbers 1-8 represent the treatments S1-S8.

\section{Materials and Methods}

\subsection{Experimental Design}

Because the soil and vegetation were completely destroyed during the construction of roads and slopes, the developers filled the slopes with soil and planted shrubs to restore the ecological environment. During the implementation of the project, four kinds of soils, including weathered rock soil, coarse silty soil, collapsible loess, and liquefaction soil of saline soil with sandy soil were filled (Figure 2), and two plant species (H. rhamnoides Linn. and C. korshinskii) were planted. To determine which soil and vegetation allocation provided better soil and water conservation benefits, eight representative treatment areas were selected according to the actual situation of the project area. Specific information on the soil and vegetation allocation in each treatment area is shown in Table 1.

Table 1. Basic information of the treatments along the expressway in Datong City, Shanxi Province, China.

\begin{tabular}{|c|c|c|c|c|c|c|}
\hline Number & Treatments & $\begin{array}{l}\text { Specification } \\
(\mathrm{m})\end{array}$ & Soil Type & $\begin{array}{l}\text { Soil Thickness } \\
\text { (cm) }\end{array}$ & Plant Species & Slope Ratio \\
\hline 1 & S1 & $10 \times 20$ & Weathered rock soil & 43 & \multirow{4}{*}{ C. korshinskii } & \\
\hline 2 & S2 & $10 \times 20$ & Coarse silty soil & 40 & & \\
\hline 3 & S3 & $10 \times 20$ & Collapsible loess & 45 & & \\
\hline 4 & S4 & $10 \times 20$ & $\begin{array}{l}\text { Liquefaction soil of saline } \\
\text { soil with sandy soil }\end{array}$ & 39 & & $1: 1.5$ \\
\hline 5 & S5 & $10 \times 20$ & Weathered rock soil & 43 & \multirow{4}{*}{$\begin{array}{l}\text { H. rhamnoides } \\
\text { Linn. }\end{array}$} & \\
\hline 6 & S6 & $10 \times 20$ & Coarse silty soil & 40 & & \\
\hline 7 & S7 & $10 \times 20$ & Collapsible loess & 45 & & \\
\hline 8 & S8 & $10 \times 20$ & $\begin{array}{l}\text { Liquefaction soil of saline } \\
\text { soil with sandy soil }\end{array}$ & 39 & & \\
\hline
\end{tabular}




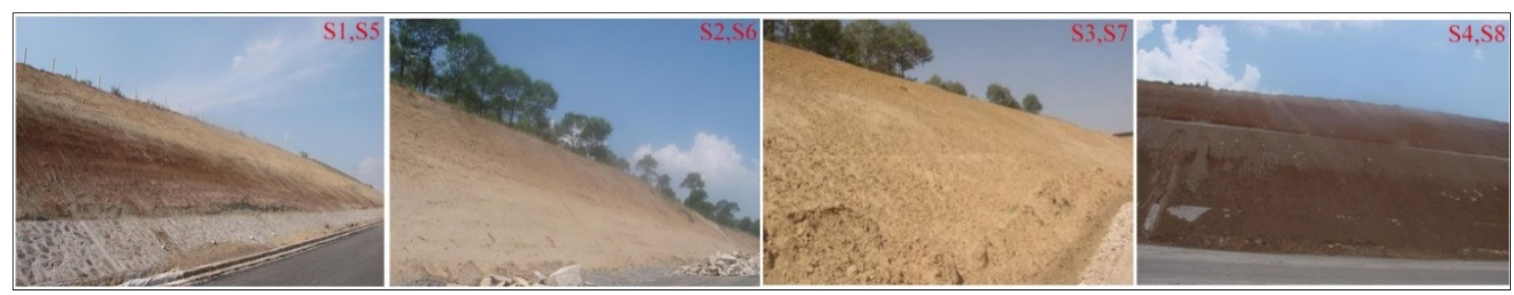

Figure 2. Filled soil in the different treatments: S1 and S5 were the weathered rock soil; S2 and S6 were the coarse silty soil; S3 and S7 were the collapsible loess; S4 and S8 were the liquefaction soil of saline soil with sandy soil.

\subsection{Soil Sample Collection}

All samplings and erosion observations were performed in 2013. For the eight treatments along the expressway, nine sampling points were selected for each treatment. At each sampling point, soil samples were collected from the undisturbed original slope surface using a ring knife at depths of 0-20 cm, 20-40 cm, 40-60 cm, and 60-80 cm. The samples were brought to the laboratory to determine the volume weight of soil (VWS) and total porosity (TP). Additional soil samples were collected using an aluminum box to measure the soil moisture content (SWC) at the four soil depths, using the dry weighing method [23], and to determine soil organic matter levels via the potassium dichromate method [24]. Three soil samples were collected from each soil layer for each analysis.

\subsection{Determination of Soil Physical Properties}

\subsubsection{Total Soil Porosity}

To measure soil porosity, we opened the lower cover of the ring knife (with the mesh end), put it onto filter paper, and immediately weighed the sample $\left(\mathrm{m}_{1}\right)$. Subsequently, we removed the upper cover of the ring cutter and placed the mesh end of the ring cutter into the basin. The height of the water layer in the bowl was up to the edge of the knife (not submerged). After 12 hours of water absorption, we removed the ring knife, covered the lid, and weighed the sample again $\left(\mathrm{m}_{2}\right)$. After weighing, the ring cutter (bottom end of the mesh) was placed in a flat pan with dry sand and weighed $\left(\mathrm{m}_{3}\right)$ after $12 \mathrm{~h}$. After weighing, the ring knife (mesh side down) was placed in a flat pan again and weighed $\left(\mathrm{m}_{4}\right)$ immediately after infiltration for $12 \mathrm{~h}$. The weighed ring knife cover was opened, placed in an oven at $105^{\circ} \mathrm{C}$ for $24 \mathrm{~h}$, covered, and weighed $\left(\mathrm{m}_{5}\right)$. Subsequently, soil porosity was calculated as follows:

$$
\mathrm{P}=\left(\frac{\mathrm{m}_{2}-\mathrm{m}_{5}}{\mathrm{v}}\right) \times 100 \%
$$

where $\mathrm{P}$ is total porosity $\left(\mathrm{g} / \mathrm{cm}^{3}\right)$ and $\mathrm{v}$ is the volume of the ring cutter.

\subsubsection{Volume Weight of The Soil}

The VWS was measured using the ring knife method [25]. We ensured that the soil in the ring cutter was not disturbed during each operational step. The ring cutter with the soil sample was placed in an oven at $105^{\circ} \mathrm{C}$ and dried to constant weight; afterwards, the ring knife with soil samples $\left(\mathrm{m}_{1 \mathrm{j}}\right)$ and the soil samples $\left(\mathrm{m}_{2 \mathrm{j}}\right)$ were weighed separately, and the VWS was calculated as follows:

$$
V W S=\frac{\sum_{j=1}^{3}\left(m_{1 j}-m_{2 j}\right)}{3 v}
$$

where the $\mathrm{v}$ is the volume of the ring cutter, and $\mathrm{J}=1,2$, and 3 is the repeat number of the same soil layer. 


\subsubsection{Soil Organic Matter}

We used the potassium dichromate oxidation-external heating method to determine soil organic matter (SOM). Briefly, the soil mixture is boiled with potassium dichromate oxidizer and sulfuric acid $(95 \%)$ in an oil bath at $170-180^{\circ} \mathrm{C}$ for $5 \mathrm{~min}$. The carbon in the SOM was oxidized to carbon dioxide by potassium dichromate, while the hexavalent chromium in the potassium dichromate was reduced to trivalent chromium. The remaining potassium dichromate was then titrated with standard solution of ferrous oxide. According to the amount of ferrous sulfate consumed by potassium dichromate before and after oxidation of organic carbon, the content of organic carbon was calculated and converted into SOM.

\subsubsection{Soil Erosion}

During the observation period, runoff barrels were used to collect runoff and sediment samples in the eight treatment plots. Weighing-sedimentation-drying-weighing and sampling-drying-weighing were used to correct the runoff and sediment yields, respectively. Hydraulic erosion per hectare was obtained through the area of the plot [26]. Secondly, wind erosion was measured via the cutting method [27]. The first choice is to record the depth of cutting, measure the change depth of cutting after the observation period, and, finally, calculate the wind erosion.

\subsubsection{Evaluation of Benefits of Soil and Water Conservation of Different Treatments by the GCM}

Here, $X_{0}$ is the reference series and $X_{i}$ the comparison series. The value of the reference series represents the maximum value of each test indicator. First, we calculated the absolute value of the difference between each corresponding point of comparison sequence $X_{i}$ and reference sequence $X_{0}$, and the GCM was evaluated as follows:

$$
\begin{gathered}
\Delta \mathrm{i}(k)=\left|\mathrm{X}_{0}(k)-\mathrm{X}_{i}(k)\right| \\
\mathrm{X}_{0}=\left\{\mathrm{X}_{0}(1), \mathrm{X}_{0}(2), \mathrm{X}_{0}(3), \ldots \ldots, \mathrm{X}_{0}(n)\right\} \\
\mathrm{X}_{i}=\left\{\mathrm{X}_{i}(1), \mathrm{X}_{i}(2), \mathrm{X}_{i}(3), \ldots \ldots \mathrm{X}_{i}(\mathrm{n})\right\}, i=1,2,3, \ldots \ldots, m .
\end{gathered}
$$

When using this approach, the actual value of each index must be converted into an evaluation value, and the original data should be processed without a dimension, according to the reference series data. On the one hand, the influence brought by each index dimension should be removed [28]; however, on the other hand, this indicator can also reflect the relative dominance of the community.

We used the formula $\mathrm{X}_{i}(\mathrm{k})=$ original data sequence/reference data sequence to perform non-dimensionalization, reducing all data return to the $[0,1]$ interval.

Subsequently, we determined the second-order maximum difference and the second-level minimum difference and calculated the correlation coefficient:

$$
\xi_{i}(k)=r X_{0}(k), X_{i}(k)=\frac{\operatorname{minmin} \Delta_{i}(k)+\rho \operatorname{maxmax} \Delta_{i}(k)}{\Delta_{i}(i)+\rho \operatorname{maxmax} \Delta_{i}(k)}=\frac{\Delta_{\min }+\rho \Delta_{\max }}{\Delta_{0, i}(k)+\rho \Delta_{\max }}
$$

where $\xi_{i}(k)$ represents the relative value of the $\mathrm{k}$ point comparison curve $\left(\mathrm{X}_{i}\right)$ and the reference curve $\left(\mathrm{X}_{0}\right)$; that is, the $\mathrm{X}_{i}{ }^{\prime} \mathrm{s}$ correlation coefficient of $\mathrm{X}_{\mathrm{o}}$ at point $\mathrm{k}$. When $\Delta 0, i(\mathrm{k})$ represents the absolute value of the $X_{0}$ sequence and the $X_{i}$ sequence at the k point, $1 \leq \mathrm{i} \leq \mathrm{m}, \mathrm{m}$ was positive; $\Delta \min$ and $\Delta \mathrm{max}$, respectively, represent the minimum and maximum values of the absolute difference of all comparison points in each point; $\rho$ is the resolution coefficient ranging from $0-1$. Here, $\rho$ was artificially set to 0.5 (the artificial coefficient for qualitative analysis) to weaken the distortion effect caused by the excessively large maximum value to increase the significance of the difference between the correlation coefficients:

$$
\mathrm{r}_{i}=\frac{1}{\mathrm{n}} \sum_{k=1}^{n} \xi_{i}(k)
$$


where $r_{i}$ indicates the degree of gray correlation; $\xi$ indicates the gray correlation coefficient.

To measure the importance of each index more realistically and objectively, the coefficient of variation $\mathrm{W}_{i}$ was calculated using the coefficient of variation method:

$$
\mathrm{W}_{i}=\frac{\mathrm{r}_{i}}{\sum \mathrm{r}_{i}}
$$

Subsequently, we calculated the gray comprehensive evaluation value $G(k)$ with the correlation degree value:

$$
G_{k}=\sum_{k=1}^{n} \xi_{i}(k) \mathrm{W}_{i}
$$

\subsection{Statistical Analysis}

Statistical analyses were performed using the software package SPSS 16.0. Descriptive statistics was used to calculate the mean and standard deviations for each set of replicates. First, a two-way ANOVA was used to analyze the differences in the SOM and SWC ( $n=27$ for each soil stratum), with treatment and soil depth as the independent factors. Two-way ANOVA was also used to analyze the differences in the SPT ( $n=27$ for each soil stratum), with treatment and soil particle size as independent factors. One-way ANOVA was also performed to test the effects of VWS, TP, $\mathrm{W}_{\mathrm{r}} \mathrm{E}$, and $\mathrm{W}_{\mathrm{d}} \mathrm{E}$ on all treatments. All data were tested for normal distribution and homogeneity of variance analysis, meeting the requirements of variance analysis.

\section{Results and Discussion}

\subsection{Basic Meteorological Characteristics}

The study area is a temperate continental monsoon climate region, with an annual average precipitation of $384.02 \mathrm{~mm}$. In 2013, average precipitation reached $418.7 \mathrm{~mm}$, which was $9.03 \%$ higher than annual average precipitation (Figure 3). Precipitation from June to September was $296.1 \mathrm{~mm}$, accounting for $70.71 \%$ of the total precipitation. Daily average precipitation was $1.14 \mathrm{~mm}$, and maximum precipitation was $45.9 \mathrm{~mm}$ on September 9. During 2013, average daily temperature was $2.1^{\circ} \mathrm{C}$, with a single-peak "convex" pattern with seasonal changes. This gradually increased from January to July, reaching a maximum of $26.7^{\circ} \mathrm{C}$ on July 30. After this peak, temperatures gradually decreased. The average daily wind speed was $1.04 \mathrm{~m} / \mathrm{s}$, with distinct differences between the seasons.

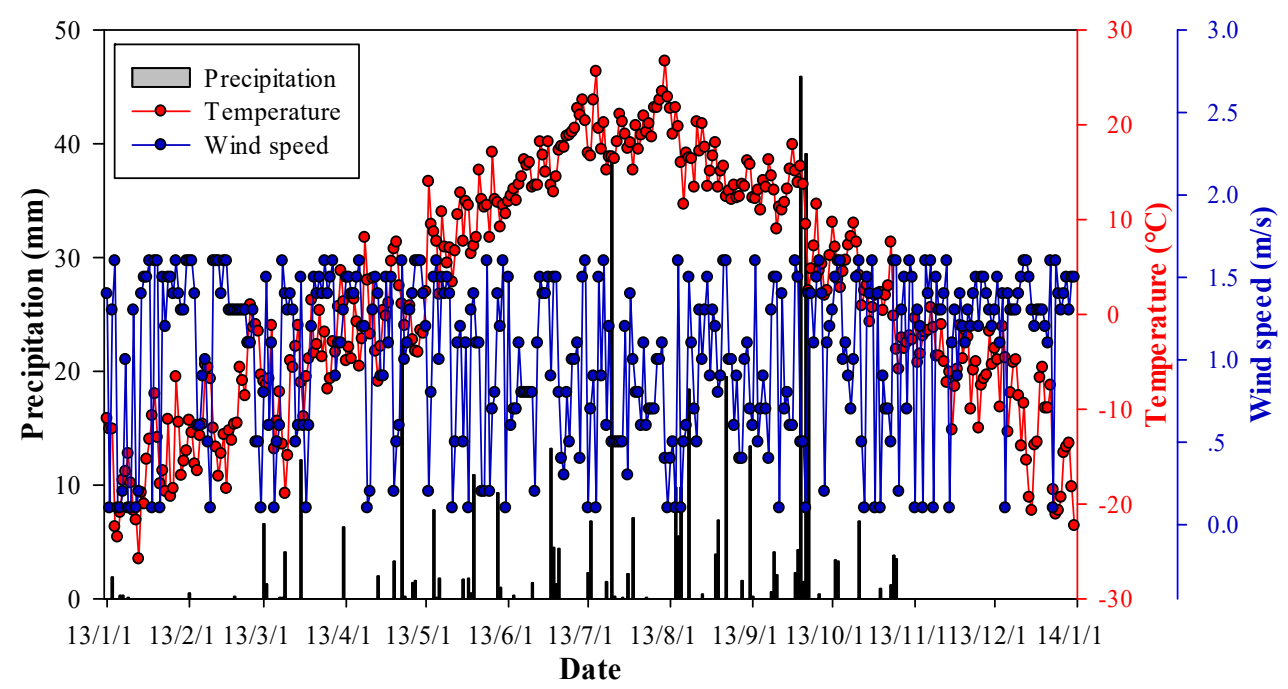

Figure 3. Precipitation, temperature, and wind speed in the study area along the expressway in Datong City, Shanxi Province, China, in 2013. 


\subsection{Weight Percentage of Soil Particle Size Under Different Treatments}

Previous studies have stated that with decreasing soil particle diameter, the soil cohesiveness gradually increased [29-31]. According to the international classification standard of particles, when a particle of a sample has a diameter of 2-64 mm, it is called "gravel" [32]. In our study, the distribution of the particle size of the samples greatly varied among the different treatments (Figure 4). Site S2 contained the largest amount of gravel among all treatments, accounting for $25.35 \%$. In the other treatments, the proportion of gravel was smaller, or gravel was completely absent. Particles with a diameter of $0.05-1 \mathrm{~mm}$ were most abundant in S8, with a significant difference when compared to the other treatments $(p<0.05)$. The weight percentages of $d=0.05-1 \mathrm{~mm}$ were $48.86 \%, 35.18 \%, 41.35 \%$, $50.28 \%$, and $61.72 \%$, respectively, for the treatments S1, S2, S3, S7, and S8, which were significantly higher than those for the other particle size compositions $(p<0.05)$. The proportions of particles with a diameter of $<0.005 \mathrm{~mm}$ were $39.52 \%$ and $38.65 \%$, respectively, in the treatments S4 and S5, which were significantly higher than those in the other treatments $(p<0.05)$. Lu et al. also found that the size of the soil particles in the soil matrix differed; this was not only the case for the surface soil layers, but also for soil porosity in general [33]. Sandy soil contains coarse gravel and has a high soil porosity. On the contrary, the permeability of loam or clayey soil is lower than that of sandy soil, facilitating surface runoff [34]. Soil particle size and runoff are closely related, and a favorable soil particle size composition can effectively maintain water, nutrients, and organic matter [35]. According to our results, most of the particles with a diameter of more than $2 \mathrm{~mm}$ retain the original mineral composition of the parent rock. There are few available mineral nutrients, and the ability to absorb water was also poor. When the content of gravel in the soil exceeds $20 \%$ of the total volume of sample, changes in the temperature of the sample will be aggravated, and the water-holding capacity of the soil will be reduced [36].

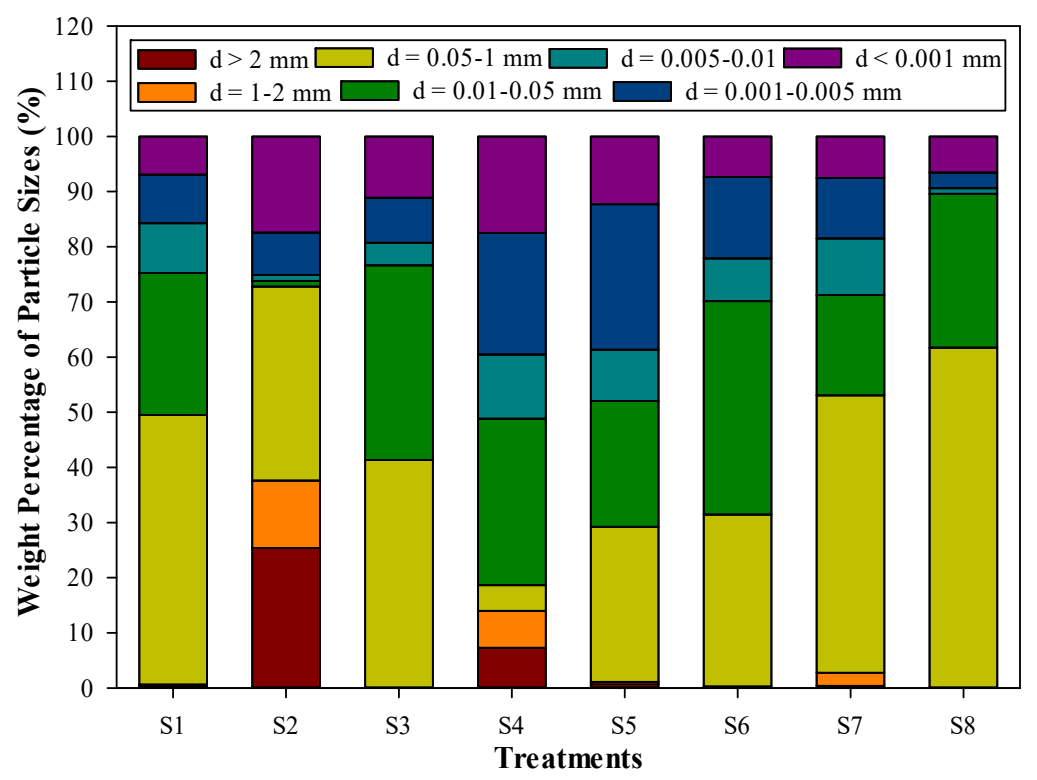

Figure 4. Variation in weight percentage of particle size of the samples under different treatments along the expressway in Datong City, Shanxi Province, China, in 2013. d represents soil particle diameter.

\subsection{Variations in Volume Weight of the Soil and Total Porosity under Different Treatments}

The volume weight of the soil (VWS) can be used as an indicator of soil solidity under certain conditions. At the same soil texture, soil with a low volume weight is relatively loose, while soil with a high VWS tends to be firm [36]. Generally, VWS varies greatly with soil texture, structure, and tightness [37]. Total porosity (TP) represents the percentage of soil porosity of the total soil volume. The amount of soil pores is related to the water permeability, air permeability, thermal conductivity, and compactness of the soil [38]. In our study, VWS and total porosity differed among the different 
treatments (Figure 5). The VWS was highest in S8, reaching $1.60 \mathrm{~g} / \mathrm{cm}^{3}$, and lowest in S3, with a value of $1.34 \mathrm{~g} / \mathrm{cm}^{3}$, with a difference of $19.4 \%$. The VWS of $S 1$ was $1.54 \mathrm{~g} / \mathrm{cm}^{3}$, with no significant difference between S1 and S7 $(p>0.05)$. The VWS values of S2 and S4 were 1.47 and $1.46 \mathrm{~g} / \mathrm{cm}^{3}$, respectively, also without a significant difference $(p>0.05)$. The VWS values of S1 and S8 were lager, while those of S3 and S5 were smaller, indicating a low soil compactness of S3 and S5, which is more suitable for plant growth. The TP values of S3, S5, and S8 were relatively high with $59.12 \%, 58.97 \%$, and $58.97 \%$, respectively, while that of $S 4$ was $53.12 \%$ and therefore smaller than the values found for S3, S5, and S8. Generally, the TP ranged between $50 \%$ and $60 \%$, and the texture was loose, which may not be conducive to water and fertilizer conservation.

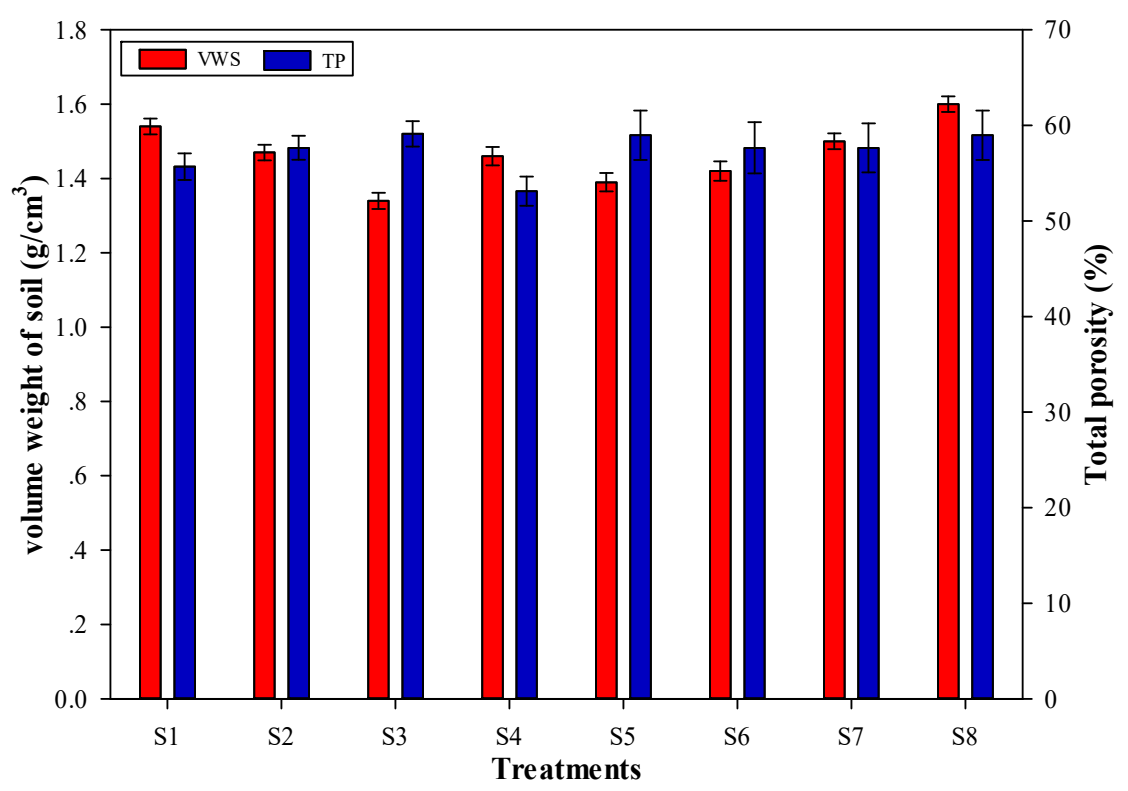

Figure 5. Variations $( \pm S D)$ in volume weight of the soil and total porosity under different treatments along the expressway in Datong City, Shanxi Province, China, in 2013. VWS and TP represent volume weight of the soil and total porosity, respectively.

\subsection{Variations in Soil and Water Content and Soil Organic Matter under Different Treatments}

The soil water content (SWC) is mainly affected by both precipitation and evaporation [39]. In our study area, SWC and SOM levels differed greatly among the different treatments, most likely because of the inherent soil characteristics. The SWC levels increased with increasing soil depth, which might be explained by the high evaporation of the surface soil, resulting in low water content. However, SOM levels decreased with increasing soil depth (Figure 6). This, owing to these surface soil layers, can easily be supplemented with organic matter. The changes in SWC among treatments ranged from $9.6 \%$ of the average SWC of S2 to $18.8 \%$ of the average SWC of S4. The average SWC of S4 was twice the average SWC of S2. The average SWC levels of S1, S3, S5, S6, S7, and S8 were $10.3 \%, 14.5 \%, 17.9 \%$, $14.8 \%, 12.7 \%$, and $16.3 \%$, respectively, following the order S4 $>$ S5 $>$ S $8>$ S6 $>$ S3 $>$ S7 $>$ S1 $>$ S2 . The average SOM level of S8 was $0.40 \%$, which was highest than in the other treatments, but still relatively low when compared with the lowest Grade 6 of the second National Soil Census and related standards $(<0.6 \%)$ [40]. The average SOM content of S6 was $0.17 \%$, which was $57.5 \%$ lower than that of S8. The average SOM levels of S1, S2, S3, S4, S5, and S7 were $0.23 \%, 0.25 \%, 0.23 \%, 0.20 \%, 0.19 \%$, and $0.22 \%$, respectively, following the order S8 $>\mathrm{S} 2>\mathrm{S} 1>\mathrm{S} 3>\mathrm{S} 7>\mathrm{S} 4>\mathrm{S} 5>\mathrm{S} 6$. The nutrient contents of the treatments were relatively low, without $\mathrm{SOM}$, and the soils are therefore not suitable for the growth of newly transplanted. Most shrub species, when transplanted into a new environment, require adequate SOM levels to adapt and grow, in contrast to naturally growing shrubs, which have adapted to these environments through natural selection. 


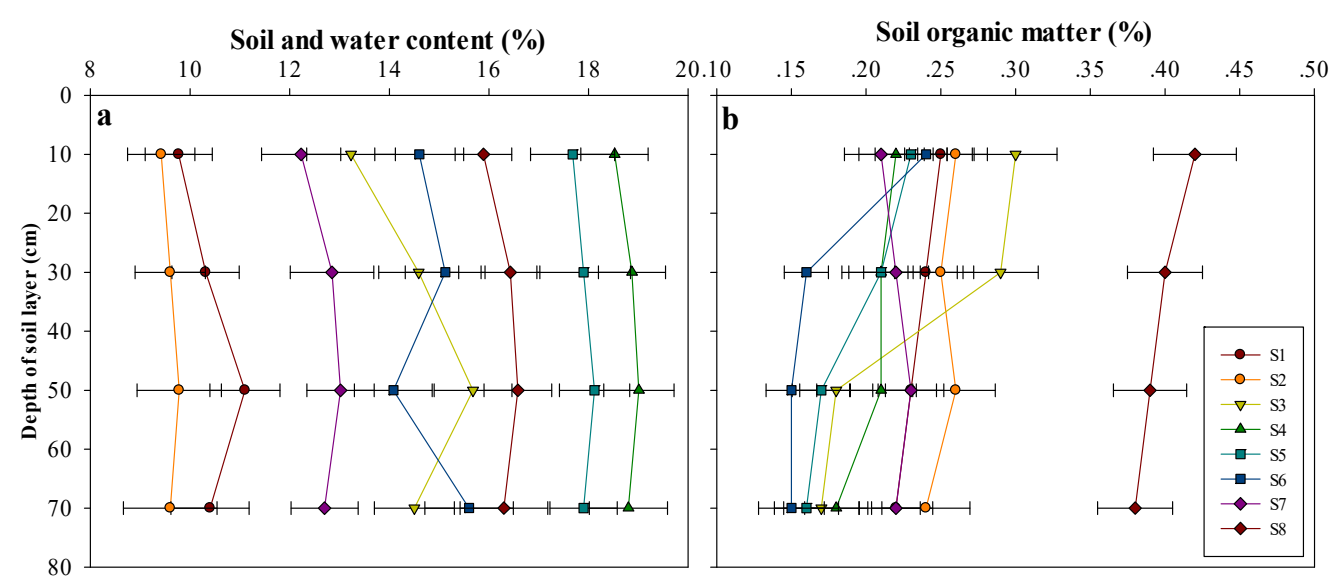

Figure 6. Variations $( \pm S D)$ in soil and water content and soil organic matter under different treatments along the expressway in Datong City, Shanxi Province, China, in 2013. a and b represent the variations in soil and water content and soil organic matter, respectively.

\subsection{Variation in Soil Erosion under Different Treatments}

During the observation period, the water erosion $\left(\mathrm{W}_{\mathrm{r}} \mathrm{E}\right)$ of the different treatments varied because of the different soil properties. Throughout the study area, water erosion was greater than wind erosion $\left(\mathrm{W}_{\mathrm{d}} \mathrm{E}\right)$, ranging between 36 and $80 \mathrm{t} / \mathrm{ha}$, while $\mathrm{W}_{\mathrm{d}} \mathrm{E}$ was between 7 and $24 \mathrm{t} / \mathrm{ha}$ (Figure 7$)$. According to the classification of soil erosion intensity in China (SL190-2007), this area is moderately affected by soil erosion. The average $\mathrm{W}_{\mathrm{r}} \mathrm{E}$ of $\mathrm{S} 4$ was the largest (69.70 $\mathrm{t} / \mathrm{ha}$ ), while that of $\mathrm{S} 3$ was the smallest (39.70 t/ha). The $\mathrm{W}_{\mathrm{r}} \mathrm{E}$ of S3 was $43.03 \%$ lower than that of S4. The WE values of S2, S6, and S7 were relatively similar and reached about $50 \mathrm{t} / \mathrm{ha}$. In S3 and S4, wind erosion was lower (8.10 and 8.63 $\mathrm{t} / \mathrm{ha}$, respectively), while at $\mathrm{S} 7$ and $\mathrm{S} 8$, it was higher (21.91 and $21.75 \mathrm{t} / \mathrm{ha}$, respectively). The $\mathrm{W}_{\mathrm{d}} \mathrm{E}$ values of S7 and S8 were 2.70 and 2.52 times higher than those of S3 and S4, respectively. We found no significant differences in $\mathrm{W}_{\mathrm{d}} \mathrm{E}$ among $\mathrm{S} 1, \mathrm{~S} 2$, S5, and $\mathrm{S} 6(p>0.05)$. With increasing soil porosity, $\mathrm{W}_{\mathrm{r}} \mathrm{E}$ gradually decreased; generally, these two factors are not correlated [41]. The larger porosity of the surface soil facilitated the infiltration of runoff on the slope, thereby reducing runoff on the slope and the scouring force of runoff on the surface soil [42]. At the same time, the infiltration water also increased the erosion resistance of the surface soil [43]. Although there were numerous factors affecting slope surface erosion, and the interaction among them is more complex, in general, the pore size of the surface soil plays a role in inhibiting surface erosion.
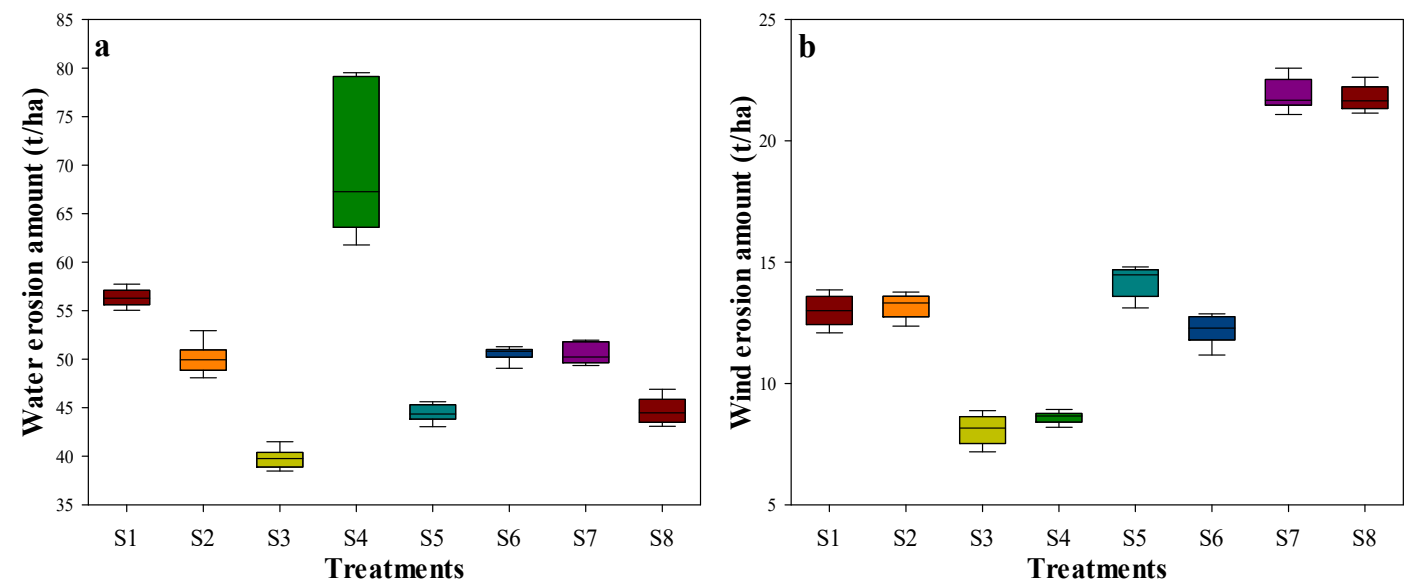

Figure 7. Variation $( \pm \mathrm{SD})$ in soil erosion amount under different treatments along the expressway in Datong City, Shanxi Province, China, in 2013. a and $\mathbf{b}$ represent the variations in water erosion and wind erosion during the experimental period. 


\subsection{Evaluation of Different Soil and Water Conservation Measures Using the GCM}

The results of comprehensive evaluations can directly reflect the effects of soil and water conservation measures $[22,44,45]$. The order of gray comprehensive evaluation values in the eight conditions was as follows: S1 (0.7593) > S7 (0.6995) > S3 (0.6656) > S8 (0.6516) > S5 (0.6485) > S2 $(0.6385)>$ S4 (0.6377) > S6 (0.6194) (Table 2). This indicates that in S1, the soil and water conservation benefits were highest, suggesting the use of this soil in restoration programs in this area. Basically, these results lead us to infer that weathered rock soil and collapsible loess can be used when repairing slopes. In terms of plant species, C. korshinskii and H. rhamnoides Linn. were planted separately to achieve the best soil and water conservation benefits. The gray comprehensive evaluation values of each index were VWS $(0.7376)>\mathrm{TP}(0.7284)>\mathrm{SPZ}(0.7233)>\mathrm{SWC}(0.5777)>\mathrm{SOM}(0.466)>\mathrm{W}_{\mathrm{r}} \mathrm{E}$ $(0.4294)>W_{d} E(0.369)$. The relationship between soil bulk density and total porosity was the most significant one, indicating that soil porosity and soil bulk density have the greatest impact on the effect of soil and water conservation measures. When repairing slopes, organic fertilizer can be applied to enhance plant growth and improve soil conditions. Additionally, adequate irrigation is necessary to support plant development.

Table 2. Correlation degrees and correlation coefficients of each evaluation index. SPZ, VWS, TP, SWC, $\mathrm{SOMC}, \mathrm{W}_{\mathrm{r}} \mathrm{E}, \mathrm{W}_{\mathrm{d}} \mathrm{E}$, and $\mathrm{G}(\mathrm{k})$ represent soil particle size, volume weight of the soil, soil water content, total soil porosity, soil organic matter, water erosion, wind erosion, and gray comprehensive evaluation value, respectively. The parameter ri and Wi indicate the degree of gray correlation and the coefficient of variation, respectively.

\begin{tabular}{ccccccccc}
\hline Treatments & SPZ & VWS & TP & SWC & SOMC & $\mathbf{W}_{\mathbf{r}} \mathbf{E}$ & $\mathbf{W}_{\mathbf{d}} \mathbf{E}$ & $\mathbf{G}(\mathbf{k})$ \\
\hline S1 & 0.7489 & 0.8513 & 0.8321 & 0.5286 & 0.3427 & 0.3388 & 0.341 & 0.7593 \\
S2 & 0.5475 & 0.7981 & 0.6162 & 0.5955 & 0.3414 & 0.3538 & 0.336 & 0.6385 \\
S3 & 0.8005 & 0.8142 & 0.784 & 0.5115 & 0.3576 & 0.4026 & 0.3492 & 0.6656 \\
S4 & 0.6653 & 0.6316 & 0.7106 & 0.8678 & 0.5932 & 0.6929 & 0.3376 & 0.6377 \\
S5 & 0.6872 & 0.7469 & 0.7106 & 0.8714 & 0.6494 & 0.4797 & 0.3347 & 0.6485 \\
S6 & 0.6872 & 0.6498 & 0.7106 & 0.5496 & 0.5772 & 0.487 & 0.4074 & 0.6194 \\
S7 & 0.8595 & 0.6427 & 0.7251 & 0.555 & 0.6653 & 0.3745 & 0.7557 & 0.6995 \\
S8 & 0.8477 & 0.8864 & 0.7988 & 0.5079 & 0.6818 & 0.3576 & 0.7233 & 0.6516 \\
ri & 0.7233 & 0.7376 & 0.7284 & 0.5777 & 0.466 & 0.4294 & 0.369 & 0.5768 \\
Wi & 0.1975 & 0.1014 & 0.1389 & 0.1577 & 0.1272 & 0.1173 & 0.16 & 0.5661 \\
\hline
\end{tabular}

\section{Conclusions}

We observed significant differences in soil and water conservation benefits among different soil types and two shrubs species. When the gravel content of the soil exceeded $20 \%$ of the total soil volume, the changes in soil temperature are aggravated, resulting in a reduced water holding capacity. Based on the soil porosity in the area, water and organic matter conservation are not optimal, and in some sites, the soil condition was not suitable for plant growth. Although we found relatively different organic matter levels in the experimental sites, all levels were beyond the threshold values established by the second National Soil Census. Based on the poor water and organic matter status, plant growth is severely limited. Soil erosion resistance varied greatly among the different sites, and slope protection is crucial to ensure soil and water conservation in this area. The results of the comprehensive evaluation value indicate that the sites of S1 and S7 provide the best soil and water conservation benefits. This also shows that the region can achieve high soil and water conservation benefits through the two allocation modes for slope protection. Weathered rock soil and collapsible loess can be filled in to protect slopes in this area, and subsequently, the two shrub species C. korshinskii and H. rhamnoides Linn. can be planted separately to achieve optimum protection and to conserve soil and water. 
Author Contributions: C.J. wrote the paper; B.-p.S. conceived and designed the experiments; X.Y. (Xinxiao Yu) and X.Y. (Xiaohui Yang) analyzed the data.

Acknowledgments: This research was supported by the National Natural Science Foundation of China (Grant No. 41430747), the National Science and Technology Support Project (2015BA0804219).

Conflicts of Interest: The authors declare no conflict of interest.

\section{References}

1. Yang, J.; Liu, S.; Dong, S.; Zhao, Q.; Zhang, Z.M. Spatial analysis of three vegetation types in xishuangbanna on a road network using the network k-function. Procedia Environ. Sci. 2010, 2, 1534-1539. [CrossRef]

2. Zhang, L.T.; Gao, Z.L.; Yang, S.W.; Li, Y.H.; Tian, H.W. Dynamic processes of soil erosion by runoff on engineered landforms derived from expressway construction: A case study of typical steep spoil heap. Catena 2015, 128, 108-121. [CrossRef]

3. Nikomborirak, D. Private sector participation in infrastructure: The case of Thailand. J. Organ. Chem. 2015, 45. [CrossRef]

4. Roovers, P.; Bossuyt, B.; Igodt, B.; Hermy, M. May seed banks contribute to vegetation restoration on paths in temperate deciduous forest? Plant Ecol. 2006, 187, 25-38. [CrossRef]

5. Tian, H.; Cao, C.; Wei, C.; Bao, S.; Yang, B.; Myneni, R.B. Response of vegetation activity dynamic to climatic change and ecological restoration programs in inner mongolia from 2000 to 2012. Ecol. Eng. 2015, 82, 276-289. [CrossRef]

6. Azhari, A. Polycyclic aromatic hydrocarbons (pahs) in air and vegetation: Case study at three selected toll stations along north south expressway in Johor, Malaysia. Eur. J. Cancer 2012, 29, 1252-1256. [CrossRef]

7. Simões, M.D.S.; Rocha, J.V.; Lamparelli, R.A.C. Orbital spectral variables, growth analysis and sugarcane yield variáveis espectrais orbitais, indicadoras de desenvolvimento e produtividade da cana-de-açúcar. Sci. Agricola 2009, 66, 451-461. [CrossRef]

8. Normaniza, O; Barakbah, S.S. Parameters to predict slope stability-soil water and root profiles. Ecol. Eng. 2006, 28, 90-95. [CrossRef]

9. Sangode, S.J.; Vhatkar, K.; Patil, S.K.; Meshram, D.C.; Pawar, N.J.; Gudadhe, S.S.; Badekar, A.G.; Kumaravel, V. Magnetic susceptibility distribution in the soils of pune metropolitan region: Implications to soil magnetometry of anthropogenic loading. Curr. Sci. 2010, 98, 516-527. [CrossRef]

10. Yang, Y.; Yang, J.; Zhao, T.; Huang, X.; Ping, Z. Ecological restoration of highway slope by covering with straw-mat and seeding with grass-legume mixture. Ecol. Eng. 2016, 90, 68-76. [CrossRef]

11. Wei, Z.; Wang, J.G.; Ling, W.; Jin, L. Stability analysis and supporting system design of a high-steep cut soil slope on an ancient 1 andslide during highway construction of tehran-chalus. Environ. Earth Sci. 2012, 67, 1651-1662. [CrossRef]

12. Burt, J.W. Developing restoration planting mixes for active ski slopes: A multi-site reference community approach. Environ. Manag. 2012, 49, 636-648. [CrossRef] [PubMed]

13. Wei, H.; Shao, L.; Zhang, Z. Shrubs increase soil resources heterogeneity along semiarid grass slopes in the loess plateau. J. Arid Environ. 2013, 88, 175-183. [CrossRef]

14. Maiti, S.K.; Maiti, D. Ecological restoration of waste dumps by topsoil blanketing, coir-matting and seeding with grass-legume mixture. Ecol. Eng. 2015, 77, 74-84. [CrossRef]

15. Farnhill, T. Union renewal and workplace greening-three case studies. Br. J. Ind. Relat. 2017. [CrossRef]

16. Li, C.; Pan, C. The relative importance of different grass components in controlling runoff and erosion on a hillslope under simulated rainfall. J. Hydrol. 2018, 558, 76. [CrossRef]

17. Fore, S.; Mbohwa, C. Greening manufacturing practices in a continuous process industry. J. Eng. Des. Technol. 2015, 13, 94-122. [CrossRef]

18. Hüne, M.; González-Wevar, C.; Poulin, E.; Mansilla, A.; Fernández, D.A.; Barrera-Oro, E. Low level of genetic divergence between harpagifer fish species (perciformes: Notothenioidei) suggests a quaternary colonization of patagonia from the antarctic peninsula. Polar Biol. 2015, 38, 607-617. [CrossRef]

19. Graber, H.L.; Al, A.R.; Xu, Y.; Asarian, A.P.; Pappas, P.J.; Dresner, L.; Patel, N.; Jagarlamundi, K.; Solomon, W.B.; Barbour, R.L. Enhanced resting-state dynamics of the hemoglobin signal as a novel biomarker for detection of breast cancer. Med. Phys. 2015, 42, 6406. [CrossRef] 
20. Androff, D.; Fike, C.; Rorke, J. Greening social work education: Teaching environmental rights and sustainability in community practice. J. Soc. Work Educ. 2017, 53, 1-15. [CrossRef]

21. Wardle, G.M.; Pavey, C.R.; Dickman, C.R. Greening of arid australia: New insights from extreme years. Austral Ecol. 2013, 38, 731-740. [CrossRef]

22. Lorenz, A.J. Resource allocation for maximizing prediction accuracy and genetic gain of genomic selection in plant breeding: A simulation experiment. G3 Genes Genomes Genet. 2013, 3, 481-491. [CrossRef]

23. Zuo, Q.; Zhang, D.; Jiaqiang, E.; Gong, J. Comprehensive analysis on influencing factors of composite regeneration performance of a diesel particulate filter. Environ. Progress Sustain. Energy 2016, 35, 882-890. [CrossRef]

24. Shigeno, T.; Brock, M.; Shigeno, S.; Fritschka, E.; Cervósnavarro, J. The determination of brain water content: Microgravimetry versus drying-weighing method. J. Neurosurg. 1982, 57, 99-107. [CrossRef]

25. Walinga, I.; Kithome, M.; Novozamsky, I.; Houba, V.J.G.; Lee, J.J.V.D. Spectrophotometric determination of organic carbon in soil. Commun. Soil Sci. Plant Anal. 1992, 23, 10. [CrossRef]

26. Hacisalihoglu, S. Determination of soil erosion in a steep hill slope with different land-use types: A case study in Mertesdorf (Ruwertal/Germany). J. Environ. Biol. 2007, 28, 433-438.

27. Visser, S.M.; Sterk, G.; Ribolzi, O. Techniques for simultaneous quantification of wind and water erosion in semi-arid regions. J. Arid Environ. 2004, 59, 699-717. [CrossRef]

28. Sarkar, U.K.; Deepak, P.K.; Negi, R.S. Length-weight relationship of clown knifefish chitala chitala (hamilton 1822) from the river ganga basin, India. J. Appl. Ichthyol. 2009, 25, 232-233. [CrossRef]

29. Xia, X.; Yu, S.; Kai, W.; Jiang, Q. Optimization of a straw ring-die briquetting process combined analytic hierarchy process and grey correlation analysis method. Fuel Process. Technol. 2016, 152, 303-309. [CrossRef]

30. Martin, C.M.; Randolph, M.F. Upper-bound analysis of lateral pile capacity in cohesive soil. Geotechnique 2006, 56, 141-146. [CrossRef]

31. Biscontin, G.; Pestana, J.M.; Nadim, F. Seismic triggering of submarine slides in soft cohesive soil deposits. Marine Geol. 2004, 203, 341-354. [CrossRef]

32. Alaoui, A.; Lipiec, J.; Gerke, H.H. A review of the changes in the soil pore system due to soil deformation: A hydrodynamic perspective. Soil Till. Res. 2011, 115, 1-15. [CrossRef]

33. Lu, Q.; Wang, E.; Chen, X. Effect of mechanical compaction on soil micro-aggregate composition and stability of black soil. Trans. Chin. Soc. Agric. Eng. 2015, 31, 54-59. [CrossRef]

34. Yahya, Z.; Mohammed, A.T.; Harun, M.H.; Shuib, A.R. Oil palm adaptation to compacted alluvial soil (typic endoaquepts) in malaysia. J. Oil Palm Res. 2013, 24, 1533-1541. [CrossRef]

35. Tang, A.M.; Cui, Y.J.; Richard, G.; Défossez, P. A study on the air permeability as affected by compression of three french soils. Geoderma 2011, 162, 171-181. [CrossRef]

36. Creamer, R.E.; Brennan, F.; Fenton, O.; Healy, M.G.; Lalor, S.T.J.; Lanigan, G.J.; Regan, J.T.; Griffiths, B.S. Implications of the proposed soil framework directive on agricultural systems in atlantic europe-A review. Soil Use Manag. 2010, 26, 198-211. [CrossRef]

37. Abdu, H.; Robinson, D.A.; Seyfried, M.; Jones, S.B. Geophysical imaging of watershed subsurface patterns and prediction of soil texture and water holding capacity. Water Resour. Res. 2008, 44, 5121-5127. [CrossRef]

38. Ashraf, M.A.; Maah, M.J.; Yusoff, I. Chemical speciation and potential mobility of heavy metals in the soil of former tin mining catchment. Sci. World J. 2012, 2012, 125608. [CrossRef]

39. Ross, D.S.; Bailey, S.W.; Lawrence, G.B.; Shanley, J.B.; Fredriksen, G.; Jamison, A.E.; Brousseau, P.A. Near-surface soil carbon, carbon/nitrogen ratio, and tree species are tightly linked across northeastern united states watersheds. For. Sci. 2011, 57, 460-469. [CrossRef]

40. Shirani, H.; Rizabandi, E.; Mosaddeghi, M.R.; Dashti, H. Impact of pistachio residues on compactibility, and permeability for water and air of two aridic soils from southeast of Iran. Arid Soil Res. Rehabil. 2010, 24, 20. [CrossRef]

41. Wei, J.; Knoche, H.R.; Kunstmann, H. Contribution of transpiration and evaporation to precipitation: An et-tagging study for the poyang lake region in southeast China. J. Geophys. Res. Atmos. 2015, 120, 6845-6864. [CrossRef]

42. Zhen, L. The national census for soil erosion and dynamic analysis in china. Int. Soil Water Conserv. Res. 2013, 1, 12-18. [CrossRef] 
43. Nunes, A.N.; Lourenço, L.; Vieira, A.; Bento-Gonçalves, A. Precipitation and erosivity in southern portugal: Seasonal variability and trends (1950-2008). Land Degrad. Dev. 2016, 27, 211-222. [CrossRef]

44. Valinski, N.A.; Chandler, D.G. Infiltration performance of engineered surfaces commonly used for distributed stormwater management. J. Environ. Manag. 2015. [CrossRef]

45. Jouquet, P.; Bottinelli, N.; Kerneis, G.; Henry-des-Tureaux, T.; Doan, T.T.; Planchon, O.; Tran, T.D. Surface casting of the tropical metaphire posthuma increases soil erosion and nitrate leaching in a laboratory experiment. Geoderma 2013, 204-205, 10-14. [CrossRef]

(C) 2019 by the authors. Licensee MDPI, Basel, Switzerland. This article is an open access article distributed under the terms and conditions of the Creative Commons Attribution (CC BY) license (http://creativecommons.org/licenses/by/4.0/). 